\title{
Pythiosis cutánea en equinos tratados con acetonida de triamcinolona. Parte 1. Caracterización clínica
}

\section{Cutaneous pythiosis in horses treated with triamcinolone acetonide. Part 1. Clinical characterization}

\author{
José Cardona-Álvarez, ${ }^{1 *}$ Ph.D, Marlene Vargas-Vilória² Ph.D, \\ Joaquín Patarroyo-Salcedo, ${ }^{2}$ Ph.D.
}

\begin{abstract}
1 Universidad de Córdoba, Departamento de Ciencias Pecuarias, Grupo de Estudios e Investigaciones en Medicina de Grandes Animales (MEGA), Montería, Colombia. ${ }^{2}$ Universidad Federal de Viçosa, Departamento de Medicina Veterinaria, Viçosa, Brasil. *Correspondencia: cardonalvarez@hotmail. com
\end{abstract}

Received: December 2015; Accepted: July 2016.

\begin{abstract}
Objective. The objective of the present study was to characterizer clinically of the healing process of cutaneous pythiosis in horses treated with triamcinolone acetonide. Materials and methods. We conducted a descriptive study, not probabilistic, of convenience. 24 horses were used with cutaneous pythiosis confirmed, a group of 12 animals was administered $50 \mathrm{mg}$ of intramuscular injection of triamcinolone acetonide (TG) and the other group was not applied any treatment (CG). They are undergoing clinical and microscopic characterization of the lesion every 4 days until the complete recovery of granuloma in the GT. Being verified decreased fibrin bloody exudate, pruritus, presence of fistulae and output kunkers, likewise radiographic projections were performed to assess the degree of compromise bone and tissue fibrosis. Results. Macroscopically animals GT present progressive decrease in the clinical features of the disease at $16 \pm 1.4$ days post treatment application. The wound contraction was $100 \%$ at $60 \pm 3.4$ days after application of the treatment in all granulomas of GT, being highly significant $(p<0.0001)$. Radiological monitoring of chronic skin lesions, met invasion to underlying tissues compromising bone structures, characterized by tissue fibrosis, moderate exostosis, bake as osteolysis and osteomyelitis. Neither of the animals in the CG showed improvement in clinical characteristics, and macroscopic of pythiosis and maintained equal to the first day throughout the study. Conclusions. The use of triamcinolone acetonide is a good therapeutic alternative for the treatment of granulomatous Pythiosis wounds in horses with $100 \%$ clinical recovery.
\end{abstract}

Keywords: Pythium insidiosum, oomicosis, Kunkers, granuloma (Source: MeSh).

\section{RESUMEN}

Objetivo. El objetivo del estudio fue caracterizar clínicamente el proceso de cicatrización de la pythiosis cutánea en equinos tratados con acetonida de triamcinolona. Materiales y métodos. Se realizó un estudio descriptivo, no probabilístico, de conveniencia. Fueron utilizados 24 equinos con pythiosis cutánea. A un grupo le fue aplicado $50 \mathrm{mg}$ de acetonida de triamcinolona vía intramuscular (GT) y al otro grupo no fue aplicado tratamiento (GC). Se realizó caracterización clínica y macroscópica de la lesión cada 4 días hasta la recuperación completa del granuloma en el GT. Siendo verificada la disminución del 
exudado fibrinosanguinolento, prurito, presencia de trayectos fistulosos y salida de kunkers, también, fueron realizadas proyecciones radiológicas para evaluar el grado de compromiso óseo y fibrosis tecidual. Resultados. Macroscópicamente, los animales del GT presentaron diminución progresiva en las características clínicas de la enfermedad a los $16 \pm 1,4$ días post aplicación del tratamiento. La contracción de la herida fue del $100 \%$ a los $60 \pm 3.4$ días post aplicación del tratamiento en todos los granulomas del GT, siendo altamente significativa $(p<0.0001)$. Radiológicamente, se encontró invasión a los tejidos subyacentes comprometiendo estructuras óseas, caracterizándose por fibrosis tisular, exostosis moderada, osteólisis y osteomielitis. Los animales del GC no presentaron mejoría en las características clínicas y macroscópicas de la pythiosis y se mantuvieron iguales durante todo el estudio. Conclusiones. La acetonida de triamcinolona es una buena alternativa terapéutica en el tratamiento de las heridas granulomatosas de pythiosis en equinos con $100 \%$ de recuperación clínica.

Palabras clave: Pythium insidiosum, oomicosis, kunkers, granuloma (Fuente: MeSh).

\section{INTRODUCTION}

Pythiosis or Oomycosis is a granulomatous disease of cutaneous and subcutaneous tissue caused by Pythium insidiosum (1). It is known in Colombia as "espundia equina or phycomycosis" (2-4); in Brazil, as "ferida brava, mal dos pântanos y ferida de moda" (5); in other parts of the world as "granular dermatitis, Florida leeches, Gulf Coast fungus, bursatee and hyphomycosis" (6).

Pythium insidiosum is a microorganism classified as belonging to the Stramenopila kingdom, Pseudofungi phylum, Oomycetes class, Pythiales order, Pythiaceae family and Pythium genus, so that the members of the Oomycetes class are phylogenetically distant from the kingdom of the fungi and closest to algae (7).

The geographic distribution is extensive, pythiosis has been reported in several tropical and subtropical countries, including Brazil, Venezuela, Colombia, Argentina, Costa Rica, Guatemala, Panama, Nicaragua, Haiti and the United States (7). The environmental conditions are determinant for the development of the organism in its ecosystem. Temperatures between 30 and $40{ }^{\circ} \mathrm{C}$ are necessary for the production of zoospores, in addition to the accumulation of water in flooded regions. The great majority of cases of pythiosis were observed during or after the rainy season (8).

Marcolongo-Pereira et al (9) stated that pythiosis, since there is no efficient antimycotic treatment, generates a negative economic impact due to the death or disability of the animals in most cases, since according to Cardona et al 10,11), disabling lesions are located particularly in the limbs, mouth and chest, because they are the areas of greatest exposure to the microorganism.

The lesion is characterized by the formation of serious granulomatous, granulocytic, prominent and raised ulceration with irregular edges and

\section{INTRODUCCIÓN}

La pythiosis u Oomicosis es una enfermedad granulomatosa del tejido cutáneo y subcutáneo causada por el Pythium insidiosum (1). Es conocida en Colombia como "espúndia equina o ficomicosis" (2-4); en Brasil, como "ferida brava, mal dos pântanos y ferida de moda" (5); en otras partes del mundo, como "dermatitis granular, sanguijuelas de la Florida, hongo de la Costa del Golfo, bursatee e hifomicosis" (6).

Pythium insidiosum es un microorganismo clasificado como perteneciente al reino Stramenopila, phylum Pseudofúngi, clase Oomycetes, orden Pythiales, familia Pythiaceae y género Pythium, de modo que los miembros de la clase Oomycetes son filogenéticamente distantes del reino de los hongos y más cercanos de las algas (7).

La distribución geográfica es amplia, la pythiosis ha sido relatada en varios países tropicales y subtropicales, que incluyen Brasil, Venezuela, Colombia, Argentina, Costa Rica, Guatemala, Panamá, Nicaragua, Haití y Estados Unidos (7). Las condiciones ambientales son determinantes para el desarrollo del organismo en su ecosistema. Para que sea posible la producción de zoósporos son necesarias temperaturas entre 30 y $40^{\circ} \mathrm{C}$, además del acúmulo de agua en regiones inundables. La gran mayoría de los casos de pythiosis fue observada durante o después de la estación lluviosa (8).

Marcolongo-Pereira et al (9), expresan que la pythiosis debido a que no existe tratamiento antimicótico eficiente, genera impacto económico negativo, por la muerte o invalidez de los animales en la gran mayoría de los casos, ya que según Cardona et al $(10,11)$, las lesiones incapacitantes se ubican particularmente en los miembros, boca y pecho, debido a que son las áreas de mayor exposición al microorganismo.

La lesión se caracteriza por la formación de grave ulceración granulomatosa, granulocítica, 
in the shape of a crater, the size of the lesions depends on the site and time of evolution of the infection and can measure between 12 and 50 $\mathrm{cm}$ in diameter, with the presence of fistulous paths or cavitations formed by the oomycete in its invasive process in the granular tissue.

In pythiosis lesions, dead cells behave as a foreign body, triggering an inflammatory response of the body in order to promote phagocytosis and allow for the subsequent repair of the tissue affected, so in the repair and healing process there are necrotic masses and calcifications of a white-yellowish color containing hyphae and eosinophil infiltrates, which dimensions vary from 2 to $10 \mathrm{~mm}$ in diameter, called "kunkers", which, together with the presence of fistulous trajectories and fibrinosanguinolent discharges, are unequivocal signs of pythiosis (3).

There are new therapies available every day to eliminate the etiologic agent of pythiosis, improve tissue quality and promote tissue repair. Despite the use of antimycotics as a treatment option, there are few studies reporting favorable results and do not show results with convincing evidence of the efficacy of the treatment in cutaneous granuloma due to pythiosis (7).

Triamcinolone acetonide has been used in the therapy of joint, respiratory and ocular diseases in horses; however, it has not been used in the treatment of dermopathies such as equine cutaneous pythiosis. The purpose of this study is to clinically and macroscopically characterize the healing process of cutaneous pythiosis in horses treated with triamcinolone acetonide.

\section{MATERIALS AND METHODS}

Ethical aspects. For the accomplishment of this descriptive, non-probabilistic study, animals of convenience were naturally infected with cutaneous pythiosis. The study was approved by the Ethics Commission on Animal Use (CEUA) of the Federal University of Viçosa (UFV), process No. 74/2012. The animals were not subjected to processes that developed unnecessary pain and/or stress. The animals were immobilized taking into account the technical standards of animal handling and restraint, in compliance with the Universal Declaration of the Rights of Animals, referring to the international ethical principles for biomedical animal research CIOMS (Council for International Organizations of Medical Sciences) established by the UNESCO (United Nations Educational, Scientific and Cultural Organization) and WHO (World Health Organization) of 1949 and Law 84 of October 27, 1989 (Colombian Code for Animal Protection) (12). sobresaliente y elevada con bordes irregulares y en forma de cráter, el tamaño de las lesiones depende del sitio y tiempo de evolución de la infección y pueden medir entre 12 y $50 \mathrm{~cm}$ de diámetro, con presencia de trayectos fistulosos o cavitaciones formadas por el oomiceto en su proceso invasivo en el tejido granular.

En las lesiones de pythiosis, las células muertas se comportan como cuerpo extraño, desencadenando una respuesta inflamatoria del organismo con la finalidad de promover la fagocitosis y de permitir el posterior reparo del tejido afectado, por lo que en el proceso de la reparación y cicatrización, hay presencia de masas necróticas y calcificaciones que se desprenden fácilmente, de coloración blancoamarillentas que contienen hifas e infiltrado de eosinófilos, cuyas dimensiones varían de 2 a $10 \mathrm{~mm}$ de diámetro llamados "kunkers", que, juntamente con la presencia de trayectos fistulosos y descarga fibrinosanguinolenta son señales inequívocas de pythiosis (3).

Cada día existen nuevas terapias con el objetivo de eliminar el agente etiológico de la pythiosis, mejorar la calidad del tejido y promover reparación tisular. A pesar del uso de antimicóticos como una opción de tratamiento, hay pocos estudios relatando resultados favorables, y no muestran resultados con pruebas convincentes de la eficacia del tratamiento en granuloma cutáneo por pythiosis (7).

La acetonida de triamcinolona ha sido utilizada en la terapia de enfermedades articulares, respiratorias y oculares en caballos, sin embargo, no ha sido utilizada en el tratamiento de dermopatías como pythiosis cutánea equina. El presente estudio tuvo como objetivo caracterizar clínica y macroscópicamente el proceso de cicatrización de la pythiosis cutánea en equinos tratados con acetonida de triamcinolona.

\section{MATERIALES Y MÉTODOS}

Aspectos éticos. Para la realización de este estudio descriptivo, no probabilístico fueron utilizados animales de conveniencia infectados naturalmente con pythiosis cutánea. El estudio fue aprobado por la Comisión de Ética en el Uso Animal (CEUA) de la Universidad Federal de

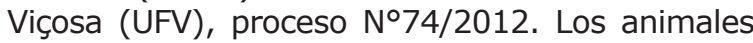
no fueron sometidos a procesos que desarrollasen dolor y/o estrés innecesario. Los animales fueron inmovilizados teniendo en cuenta las normas técnicas de manejo y sujeción de los animales, encuadradas en el cumplimiento de la Declaración Universal de los Derechos de los Animales, referente a los principios éticos internacionales para la investigación biomédica con animales CIOMS (Council for International Organizations of Medical 
Location. The experiment was carried out on the Caribbean coast of Colombia, in the department of Cordoba, located at the coordinates $7^{\circ} 23^{\prime \prime}$ and $9^{\circ} 26^{\prime}$ north latitude and $74^{\circ} 52^{\prime}$ and $76^{\circ} 32^{\prime}$ west longitude of the Greenwich meridian, at an altitude of 30 meters above sea level, with an annual average temperature of $28{ }^{\circ} \mathrm{C}$, relative humidity of $82 \%$, annual rainfall of $1.400 \mathrm{~mm}$ and a tropical forest climate. There are two well-defined seasons (rainy season and dry season) (13).

Animals. Twenty-four horses with cutaneous pythiosis of both sexes, different ages and an average weight of $380 \mathrm{~kg}$ were used. The inclusion criterion was based on the presence of clinical cutaneous pythiosis, diagnosed by the general physical examination performed during the selection process and confirmed by histopathology in the staining of Hematoxylin Eosin (HE) and Grocott (GSM).

Methodology. Animals were fed with grass and water ad libitum. Animals were divided into two groups. One group received intramuscular treatment with 50 $\mathrm{mg}$ of triamcinolone acetonide every 15 days until completing three applications (treated group - TG). The second group did not undergo any treatment (control group - CG).

All animals (TG and CG) underwent clinical evaluation and macroscopic characterization of the lesion every four days until the complete recovery of the granuloma in the TG. The reduction of the fibrinosanguinolent exudate, pruritus, presence of fistulous trajectories and exit of kunkers was verified in that evaluation; as well as the reduction of the granuloma, leveling with healthy skin and the formation of scabs.

The clinical and macroscopic characteristics of the lesions were classified from 0 to 4 taking into account the degree of clinical expression (Table 1). In addition, the animals with lesion in the distal part of the members were subject to radiological projections to evaluate the degree of bone and tissue fibrosis involvement. High-definition photographs were taken for further analysis (Sony DSC-HX10V ${ }^{\circledR}$, China).

Wound retraction was assessed from day zero until the complete closure of the granuloma by measuring the area in $\mathrm{cm}^{2}$, contoured with a permanent marker on a transparent plastic sheet of an overhead projector, to be then digitized, and the area was determined with the use of the BioEstat 5.0 software (14).

Descriptive analyzes were performed for the macroscopic evaluation of the wound (wound retraction, reduction of fibrinosanguinolent exudate, reduction of pruritus and scab formation). The variance analysis (ANOVA) was used for the comparison of the data generated for comparisons between two or more means. The ANOVA was used to verify if there
Sciences) establecida por la UNESCO (United Nations Educational, Scientific and Cultural Organization) y OMS (Organización Mundial de la Salud) de 1949 y de la Ley 84 de Octubre 27 de 1989 (Estatuto Colombiano de Protección Animal) (12).

Localización. El experimento fue desarrollado en la costa Caribe de Colombia, en el departamento de Córdoba, localizado entre las coordenadas $7^{\circ} 23^{\prime}$ e $9^{\circ} 26^{\prime}$ de latitud norte y $74^{\circ} 52^{\prime}$ e $76^{\circ} 32^{\prime}$ de longitud oeste del meridiano de Greenwich, a una altura de 30 m.s.n.m, con temperatura media anual de $28^{\circ} \mathrm{C}$, humedad relativa del $82 \%$, precipitación media anual de $1.400 \mathrm{~mm}$ y clima de bosque tropical. Hay dos estaciones bien definidas (estación lluviosa y estación seca) (13).

Animales. Fueron utilizados 24 equinos con pythiosis cutánea, de ambos sexos, diferentes edades y peso medio de $380 \mathrm{~kg}$. El criterio de inclusión fue basado en la presencia de pythiosis cutánea clínica, diagnosticada por el examen físico general realizado durante el proceso de selección y confirmados por la histopatología en las coloraciones de Hematoxilina Eosina (HE) y Grocott (GSM).

Metodología. Los animales fueron alimentados con pasto y agua ad libitum. Los animales fueron divididos en dos grupos. Un grupo recibió tratamiento intramuscular con $50 \mathrm{mg}$ de acetonida de triamcinolona cada 15 días hasta completar tres aplicaciones (grupo tratado - GT). Al segundo grupo no se le realizó tratamiento (grupo control - GC).

A todos los animales (GT y GC) se les realizó evaluación clínica y caracterización macroscópica de la lesión cada cuatro días hasta la recuperación completa del granuloma en el GT. En esa evaluación fue verificada la disminución del exudado fibrinosanguinolento, prurito, presencia de trayectos fistulosos y salida de kunkers, del mismo modo, la disminución del granuloma, nivelación con la piel saludable y la formación de la costra.

Las características clínicas y macroscópicas de las lesiones fueron estratificadas de 0 a 4 teniendo en cuenta el grado de la expresión clínica (Tabla 1). Adicionalmente, en los animales con lesión en la parte distal de los miembros fueron realizadas proyecciones radiológicas para evaluar el grado de compromiso óseo y fibrosis tisular. Fueron tomadas fotografías de alta definición para su posterior análisis (Sony DSC-HX10V ${ }^{\circledR}$, China).

A partir del día cero hasta el completo cierre del granuloma, fue evaluada la retracción de las heridas, mediante la determinación del área en $\mathrm{cm}^{2}$, siendo contorneadas con marcador permanente sobre hoja de plástico transparente de retroproyector, 
Table 1. Clinical characteristics of granulomatous lesions in horses with pythiosis subject or not to treatment with triamcinolone acetonide according to the time of the study.

\begin{tabular}{|c|c|c|c|c|}
\hline Day & Degree* & Treated Group & Degree $* 2$ & Control Group \\
\hline 0 & 4 & $\begin{array}{l}\text { Marked fibrinosanguinolent exudation } \\
\text { intense pruritus } \\
\text { Large number of fistulous trajectories } \\
\text { Marked presence of Kunkers } \\
\text { Exuberant ulcerative lesion overlying skin }\end{array}$ & 4 & $\begin{array}{l}\text { Marked fibrinosanguinolent exudation } \\
\text { intense pruritus } \\
\text { Large number of fistulous trajectories } \\
\text { Marked presence of Kunkers } \\
\text { Exuberant ulcerative lesion overlying skin }\end{array}$ \\
\hline 16 & 3 & $\begin{array}{l}\text { Absence or mild fibrinosanguinolent exudation } \\
\text { No pruritus } \\
\text { Moderate number of fistulous trajectories } \\
\text { Moderate presence of Kunkers } \\
\text { Less prominent skin lesion } \\
\text { Moderate formation of scabs at the edges of the wound } \\
\text { Contraction of the lesion by } 64.7 \%\end{array}$ & 4 & $\begin{array}{l}\text { Marked fibrinosanguinolent exudation } \\
\text { intense pruritus } \\
\text { Large number of fistulous trajectories } \\
\text { Marked presence of Kunkers } \\
\text { Exuberant ulcerative lesion overlying skin }\end{array}$ \\
\hline 32 & 2 & $\begin{array}{l}\text { Slight presence of Kunkers and fistulous } \\
\text { trajectories } \\
\text { Marked decrease in granuloma and leveling with } \\
\text { normal skin } \\
\text { Increased formation of scabs covering the wound } \\
\text { Contraction of the lesion by } 86.3 \% \text {. }\end{array}$ & 4 & $\begin{array}{l}\text { Marked fibrinosanguinolent exudation } \\
\text { intense pruritus } \\
\text { Large number of fistulous trajectories } \\
\text { Marked presence of Kunkers } \\
\text { Exuberant ulcerative lesion overlying skin }\end{array}$ \\
\hline 48 & 1 & $\begin{array}{l}\text { Formation of scabs covering the entire wound } \\
\text { Contraction of the lesion by } 97.3 \%\end{array}$ & 4 & $\begin{array}{l}\text { Marked fibrinosanguinolent exudation } \\
\text { intense pruritus } \\
\text { Large number of fistulous trajectories } \\
\text { Marked presence of Kunkers } \\
\text { Exuberant ulcerative lesion overlying skin } \\
\text { Increased wound size } \\
\text { Presence of pus }\end{array}$ \\
\hline 60 & 0 & $\begin{array}{l}\text { Absence of clinical manifestations } \\
\text { Contraction of the lesion by } 100 \%\end{array}$ & 4 & $\begin{array}{l}\text { Marked fibrinosanguinolent exudation } \\
\text { intense pruritus } \\
\text { Large number of fistulous trajectories } \\
\text { Marked presence of Kunkers } \\
\text { Exuberant ulcerative lesion overlying skin } \\
\text { Increased wound size } \\
\text { Presence of pus } \\
\text { Mutilation }\end{array}$ \\
\hline
\end{tabular}

* Degrees from 0 to 4 of lesions, where 4 is the highest expression of the disease and 0 is the total recovery of the lesion and absence of clinical signs. Source: authors

were any significant differences between the two groups ( $C G$ and $T G$ ) over time. The minimum level of statistical significance used in all tests applied was 95\% ( $\mathrm{p} \leq 0.05)$. All statistical tests were performed with the help of the computer program S.A.S. 9.1.3. (15).

\section{RESULTS}

The clinical evaluation and the anatomopathological characterization of the lesions in the horses of the study, together with the histopathological results, confirmed the diagnosis of cutaneous pythiosis according to what was reported as a diagnostic method for equine pythiosis $(3,5,10,16-19)$.

All the animals in the study (CG and $\Pi T$ ) showed the five clinical manifestations characteristic of the disease, according to Cardona et al (2-4), such as granulomatous ulceration with irregular surface, fibrinosanguinolent exudate, pruritus, fistulous trajectories with exit of purulent and caseific necrotic material called "Kunkers" (Figure 1).

The clinical and macroscopic evaluation of the lesion and its clinical evolution (wound contraction, presence of fibrinosanguinolent exudate, pruritus, fistulous trajectories, exit of posteriormente digitalizado, y el área determinada con la utilización del software BioEstat 5.0 (14).

Para la evaluación macroscópica de la herida (retracción de la herida, disminución del exudado fibrinosanguinolento, disminución del prurito y formación de la costra) fueron realizados análisis descriptivos. Para la comparación de los datos generados se utilizó el método de análisis de varianza (ANOVA) para las comparaciones entre dos o más medias. La ANOVA fue utilizada para verificar si existían diferencias significativas entre los dos grupos (GC e GT) en el de correr del tiempo. El nivel mínimo de significancia estadística utilizado en todos los test aplicados fue de 95\% ( $p \leq 0.05)$. Todos los test estadísticos fueron realizados con el auxilio del programa de computador S.A.S. 9.1.3. (15).

\section{RESULTADOS}

La evaluación clínica y la caracterización anatomopatológica de las lesiones en los caballos del estudio, junto a los resultados histopatológicos confirmaron el diagnóstico de pythiosis cutánea de acuerdo con lo reportado como método diagnóstico de la pythiosis equina $(3,5,10,16-19)$.

Todos los animales del estudio (GC y GT), presentaron las cinco manifestaciones clínicas 


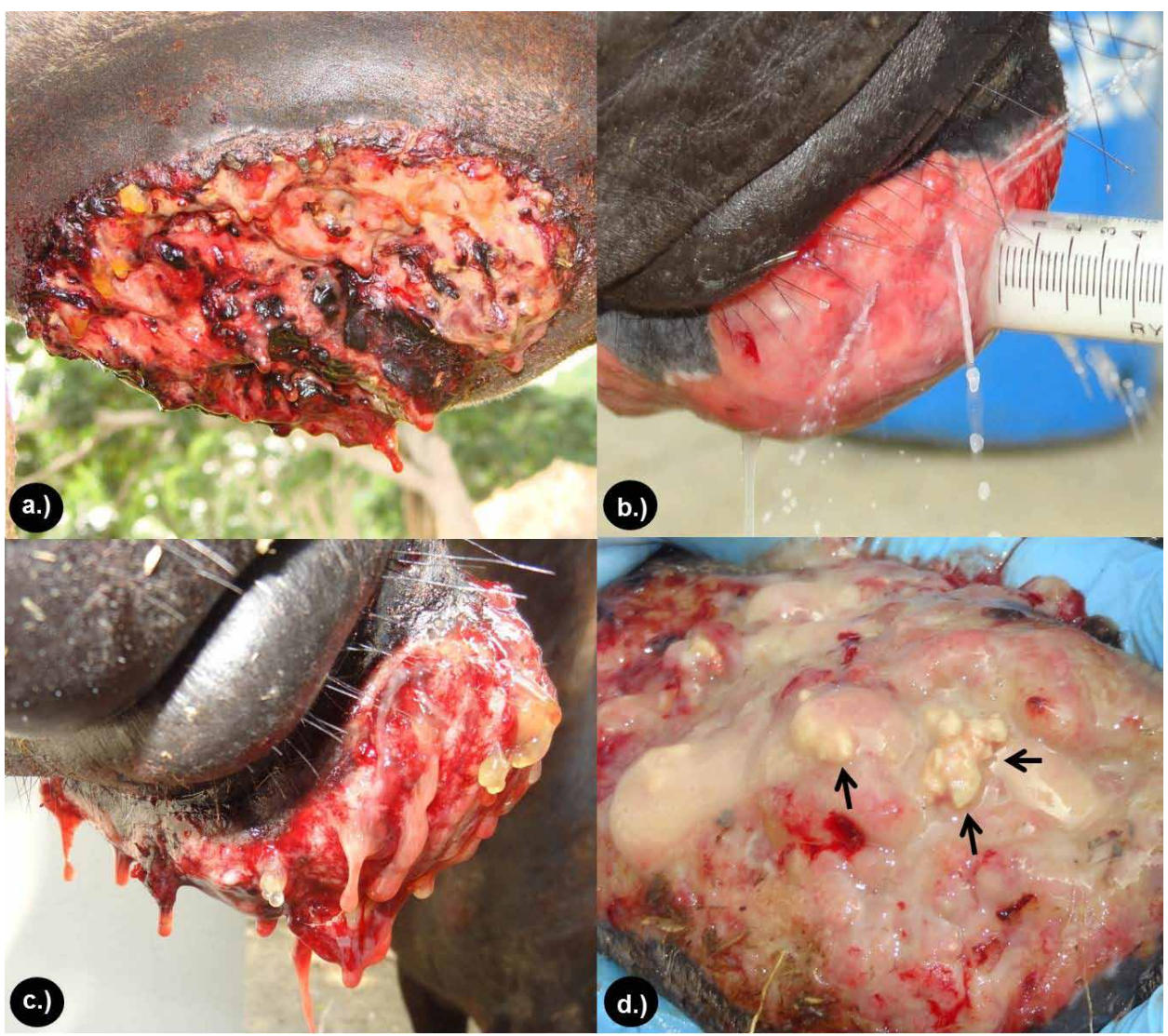

Figure 1. Clinical characterization of pythiosis on horses under study. a.) Granulomatous ulceration, prominent and elevated with irregular and crater-like edges. b.) Outflow of water from the fistulas formed by the oomycete in its invasive process in the granular tissue. c.) Fibrinosanguinolent secretion of the granulomatous lesion. D.) Exit of Kunkers or necrotic masses and calcifications that easily detach with white-yellowish coloration (black arrows).

Kunkers, and scab formation) can be observed in table 2. It was found that all TG animals showed a marked decrease in clinical characteristics, with the last observation of pruritus at $11.83 \pm 1.47$, exit of Kunkers at $13.33 \pm 1.03$, fibrionosanguinolent secretion at $14.2 \pm 1.47$ and presence of fistulous trails at $14.83 \pm 1.33$; similarly, at $16 \pm 1.4$ days after treatment, clinical signs were absent and the formation of scabs in the lesion began (Figures 2 and 3). None of the CG animals showed any improvement in the clinical characteristics of pythiosis and remained the same throughout the study. características de la enfermedad, de acuerdo a lo reportado por Cardona et al (2-4), como son la ulceración granulomatosa con superficie irregular, exudación fibrinosanguinolenta, prurito, trayectos fistulosos con salida de material necrótico purulento y caseificado llamados "Kunkers" (Figura 1).

La evaluación clínica y macroscópica de la lesión y su evolución clínica (contracción de la herida, presencia de exudado fibrinosanguinolento, prurito, trayectos fistulosos, salida de Kunkers, y formación de la costra), se puede observar en

Table 2. Graduation of the clinical characteristics of the granulomatous lesion in horses with pythiosis subject or not to treatment with triamcinolone acetonide according to the time of experiment.

\begin{tabular}{|c|c|c|c|c|c|c|c|c|c|c|c|c|}
\hline \multirow{3}{*}{ Lesion (Degree $\pm \mathrm{DE}$ ) } & \multicolumn{12}{|c|}{ Time (days) } \\
\hline & \multicolumn{2}{|c|}{ DO } & \multicolumn{2}{|c|}{ D4 } & \multicolumn{2}{|c|}{ D8 } & \multicolumn{2}{|c|}{ D12 } & \multicolumn{2}{|c|}{ D16 } & \multicolumn{2}{|c|}{ D20 } \\
\hline & GC & GT & GC & GT & GC & GT & GC & GT & GC & GT & GC & GT \\
\hline Exit of kunkers & $4.0 \pm 0.0$ & $4.0 \pm 0.0$ & $4.0 \pm 0.0$ & $3.5 \pm 0.2$ & $4.0 \pm 0.0$ & $1.7 \pm 0.5$ & $4.0 \pm 0.0$ & $1.0 \pm 0.0$ & $4.0 \pm 0.0$ & $0.0 \pm 0.0$ & $4.0 \pm 0.0$ & $0.0 \pm 0.0$ \\
\hline Fistulous trajectories & $4.0 \pm 0.0$ & $4.0 \pm 0.0$ & $4.0 \pm 0.0$ & $2.8 \pm 0.4$ & $4.0 \pm 0.0$ & $2.3 \pm 0.5$ & $4.0 \pm 0.0$ & $1.3 \pm 0.5$ & $4.0 \pm 0.0$ & $0.5 \pm 0.5$ & $4.0 \pm 0.0$ & $0.2 \pm 0.4$ \\
\hline Secretion & $4.0 \pm 0.0$ & $4.0 \pm 0.0$ & $4.0 \pm 0.0$ & $3.3 \pm 0.3$ & $4.0 \pm 0.0$ & $2.2 \pm 0.3$ & $4.0 \pm 0.0$ & $1.2 \pm 0.4$ & $4.0 \pm 0.0$ & $0.3 \pm 0.5$ & $4.0 \pm 0.0$ & $0.3 \pm 0.5$ \\
\hline Pruritus & $4.0 \pm 0.0$ & $4.0 \pm 0.0$ & $4.0 \pm 0.0$ & $3.0 \pm 0.0$ & $4.0 \pm 0.0$ & $1.7 \pm 0.5$ & $4.0 \pm 0.0$ & $0.7 \pm 0.5$ & $4.0 \pm 0.0$ & $0.0 \pm 0.0$ & $4.0 \pm 0.0$ & $0.0 \pm 0.0$ \\
\hline
\end{tabular}




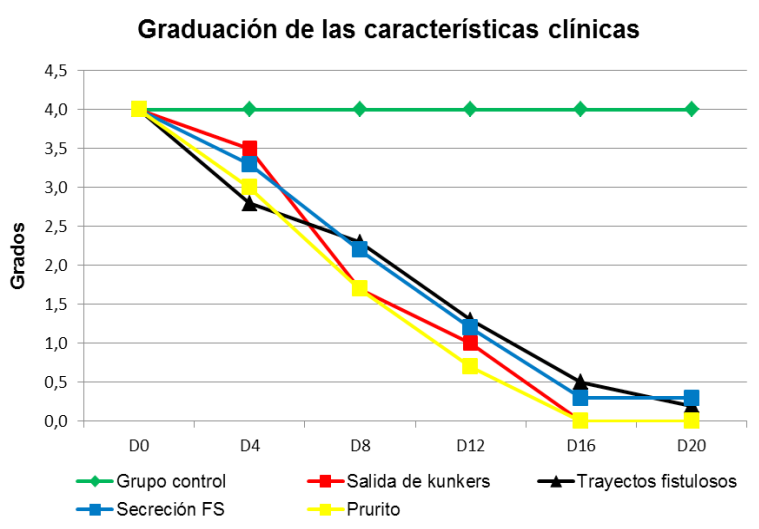

Figure 2. Proportion of the clinical characteristics of the granulomatous lesion in horses with pythiosis subject or not to treatment with triamcinolone acetonide according to the time of experiment. la tabla 2. Se encontró que todos los animales del GT presentaron disminución marcada de las características clínicas, siendo la última observación del prurito a los $11.83 \pm 1.47$, salida de Kunkers a los $13.33 \pm 1.03$, secreción fibrionosanguinolenta a los $14.2 \pm 1.47$ y presencia de trayectos fistulosos a los $14.83 \pm 1.33$, igualmente a los $16 \pm 1.4$ días después del tratamiento se presentó ausencia de los signos clínicos y comenzó la formación de la costra en la lesión (Figuras 2 y 3). Ninguno de los animales del GC presentaron mejoría en las características clínicas de la pythiosis y se mantuvieron iguales durante todo el estudio.

En la tabla 3 y figura 4, se describe la distribución de los valores medios y desviación estándar del área $\left(\mathrm{cm}^{2}\right)$ y porcentaje de contracción de la lesión granulomatosa en equinos con pythiosis

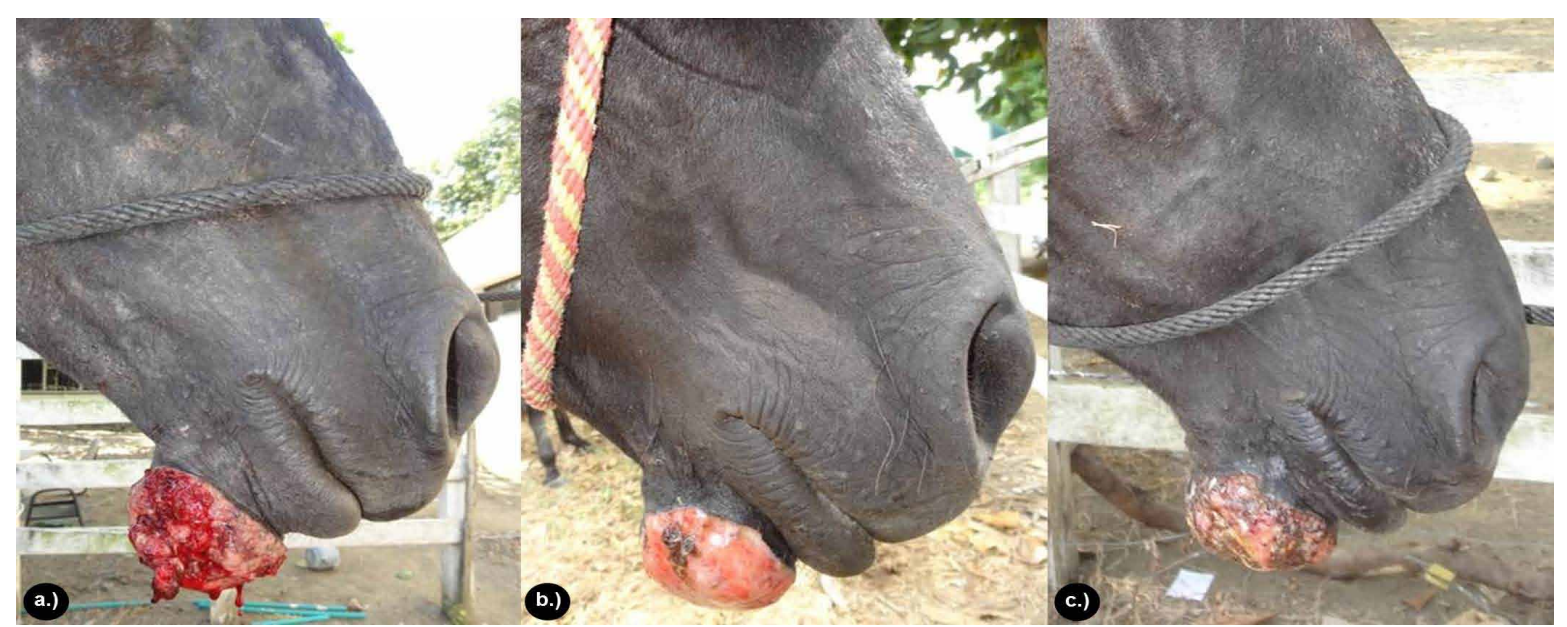

Figure 3. Clinical and macroscopic characterization of the lesion. a.) Decreased fibrinosanguinolent secretion at 4 days after treatment. b.) Decreased pruritus and onset of scab formation at 16 days after treatment. Note the absence of mutilation injuries. c.) Complete scab formation at 20 days after application of triamcinolone acetonide.

Table 3 and figure 4 describe the distribution of mean values and standard deviation of the area $\left(\mathrm{cm}^{2}\right)$ and percentage of contraction of the granulomatous lesion in horses with pythiosis subject or not to treatment with triamcinolone acetonide according to the time of the experiment. It was observed that all TG granulomas recovered in $100 \%$. So there was a significant reduction in the granuloma area at 16 days of $64.7 \%(p<0.0032)$, at 32 days of $86.3 \%(p<0.0004)$, at 48 days of $97.3 \%(p<0.0001)$ and completely closed at $60 \pm 3.4$ days $(p<0.0001)$ after the application of the treatment (Figure 5 and 6 ), as all the wounds of CG animals showed an increase of $1.9 \%$ in the area and a contraction percentage of $0,0 \%$. The Student's t test was used to

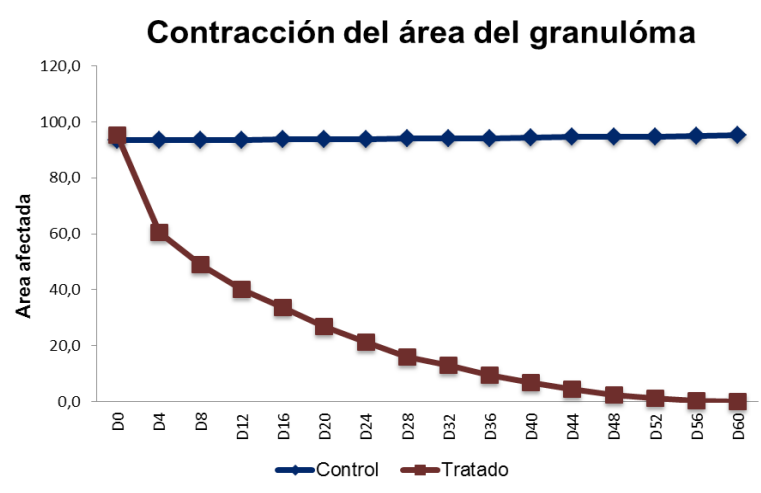

Figure 4. Mean contraction of the area of the granulomatous lesion in horses with pythiosis subject or not to treatment with triamcinolone acetonide according to the time of experiment. 
Table 3. Distribution of mean values and standard deviation of the area $\left(\mathrm{cm}^{2}\right)$, contraction percentage of granulomatous lesion and significance level in horses with pythiosis subject or not to treatment with triamcinolone acetonide according to the time of experiment.

\begin{tabular}{|c|c|c|c|c|c|c|c|}
\hline \multirow[t]{2}{*}{ Time (days) } & \multicolumn{2}{|c|}{ Application of Medicine } & \multicolumn{2}{|c|}{$\begin{array}{l}\text { TG Area } \\
\left(\mathrm{cm}^{2} \pm D E\right)\end{array}$} & \multicolumn{2}{|c|}{ Contraction of the area $(\%)$} & \multirow{2}{*}{$\begin{array}{c}\text { Significance Level } \\
\text { P- Valor }\end{array}$} \\
\hline & GT & GC & GT & GC & GT & GC & \\
\hline 0 & 1 dose AT & $\mathrm{S} / \mathrm{n}$ saline & $95.2 \pm 55.1$ & $93.4 \pm 54.8$ & 0.0 & 0.0 & 0.9336 \\
\hline 4 & --- & --- & $60.5 \pm 32.5$ & $93.4 \pm 54.8$ & 36.4 & 0.0 & 0.0875 \\
\hline 8 & --- & & $49.1 \pm 29.3$ & $93.5 \pm 54.8$ & 48.4 & 0.0 & 0.0242 \\
\hline 12 & --- & --- & $40.2 \pm 22.6$ & $93.6 \pm 54.7$ & 57.8 & 0.0 & 0.0070 \\
\hline 16 & 2 dose $A T$ & $\mathrm{~S} / \mathrm{n}$ saline & $33.6 \pm 20.7$ & $93.7 \pm 54.8$ & 64.7 & 0.0 & 0.0032 \\
\hline 20 & --- & --- & $26.9 \pm 13.8$ & $93.8 \pm 54.8$ & 71.7 & 0.0 & 0.0015 \\
\hline 24 & --- & --- & $21.2 \pm 11.0$ & $93.9 \pm 54.8$ & 77.7 & 0.0 & 0.0007 \\
\hline 28 & --- & --- & $16.0 \pm 8.1$ & $94 \pm 54.8$ & 83.2 & 0.0 & 0.0005 \\
\hline 32 & 3 dose AT & $\mathrm{S} / \mathrm{n}$ saline & $13.0 \pm 7.1$ & $94.1 \pm 54.8$ & 86.3 & 0.0 & 0.0004 \\
\hline 36 & --- & --- & $9.5 \pm 5.1$ & $94.2 \pm 54.9$ & 90.0 & 0.0 & 0.0002 \\
\hline 40 & --- & --- & $6.7 \pm 3.7$ & $94.4 \pm 55.0$ & 93.0 & 0.0 & 0.0002 \\
\hline 44 & --- & --- & $4.4 \pm 2.7$ & $94.6 \pm 55.0$ & 95.4 & 0.0 & 0.0001 \\
\hline 48 & --- & --- & $2.6 \pm 1.8$ & $94.7 \pm 55.0$ & 97.3 & 0.0 & 0.0001 \\
\hline 52 & --- & --- & $1.2 \pm 1.1$ & $94.8 \pm 55.0$ & 98.7 & 0.0 & 0.0001 \\
\hline 56 & --- & --- & $0.4 \pm 0.5$ & $95.0 \pm 55.0$ & 99.6 & 0.0 & 0.0001 \\
\hline 60 & --- & --- & $0.0 \pm 0.0$ & $95.2 \pm 55.1$ & 100 & 0.0 & 0.0001 \\
\hline
\end{tabular}
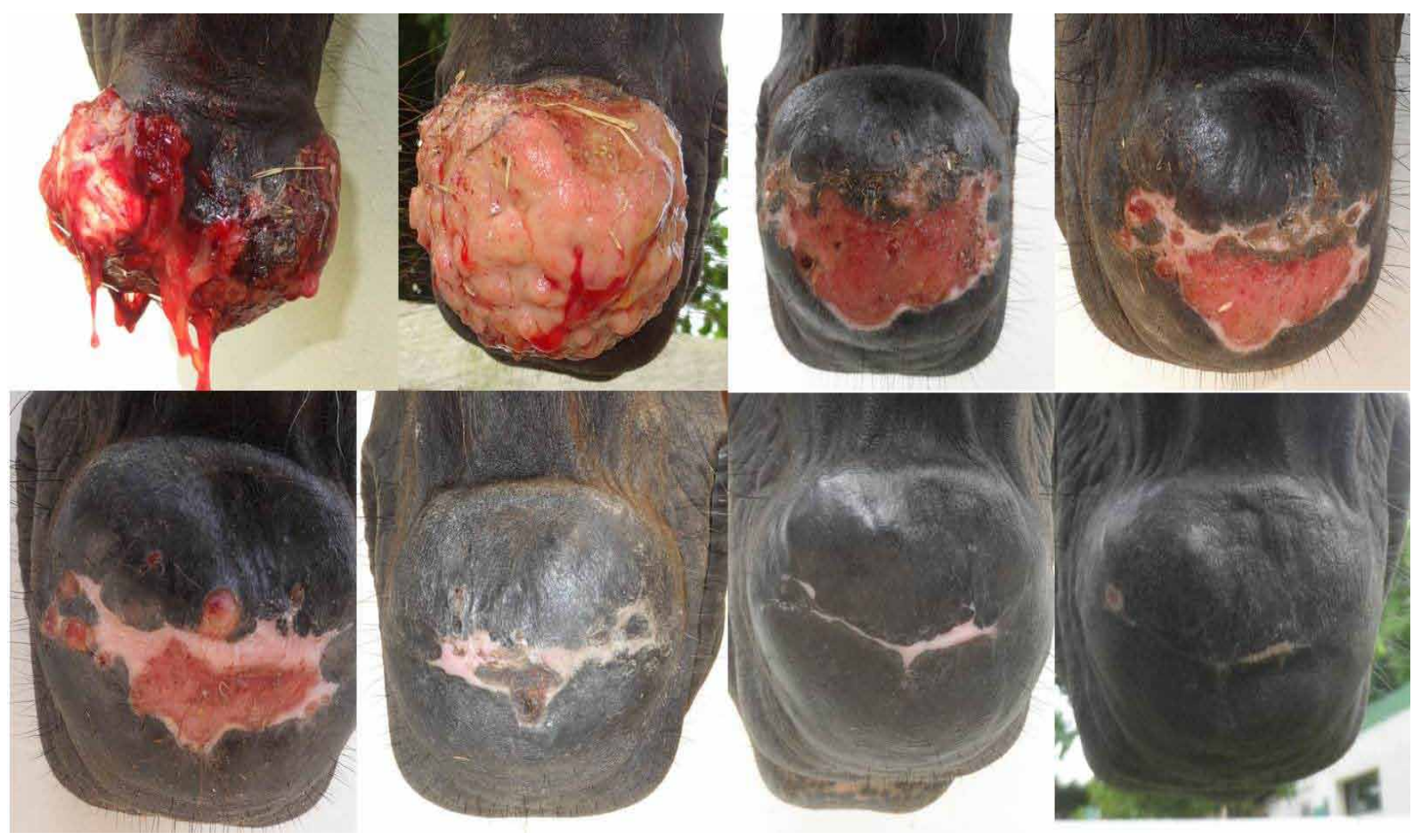

Figure 5. Contraction of the granuloma area in the TG at the chin. Note the evolution of wound contraction over a period of eight days until completely closed at $60 \pm 3.4$ days after application of treatment.

determine highly significant differences $(p=0.0001 \leq 0.05)$ between the two groups (TG and $\mathrm{CF}$ ). Considering as a response variable to the reduction in the affected area in a period of $60 \pm 3.4$ days in the treated group.

Regarding the radiological follow-up of chronic cutaneous lesions located in the distal parts of 3 animals in the study, the dorsum-palm and lateral-medial projections showed the development or invasion of the underlying sometidos o no al tratamiento con acetonida de triamcinolona de acuerdo con el tiempo de experimento. Se observó que todos los granulomas del GT se recuperaron en un $100 \%$. Por lo que, a los 16 días tenía una reducción significativa del área del granuloma de $64.7 \%(p<0.0032)$, a los 32 días de $86.3 \%(p<0.0004)$, a los 48 días de $97.3 \%(p<0.0001)$ y cerraron completamente a los $60 \pm 3.4$ días $(p<0.0001)$ después de la aplicación del tratamiento (Figura 5 y 6 ), en cuanto que todas las heridas de los animales del GC tuvieran aumento 


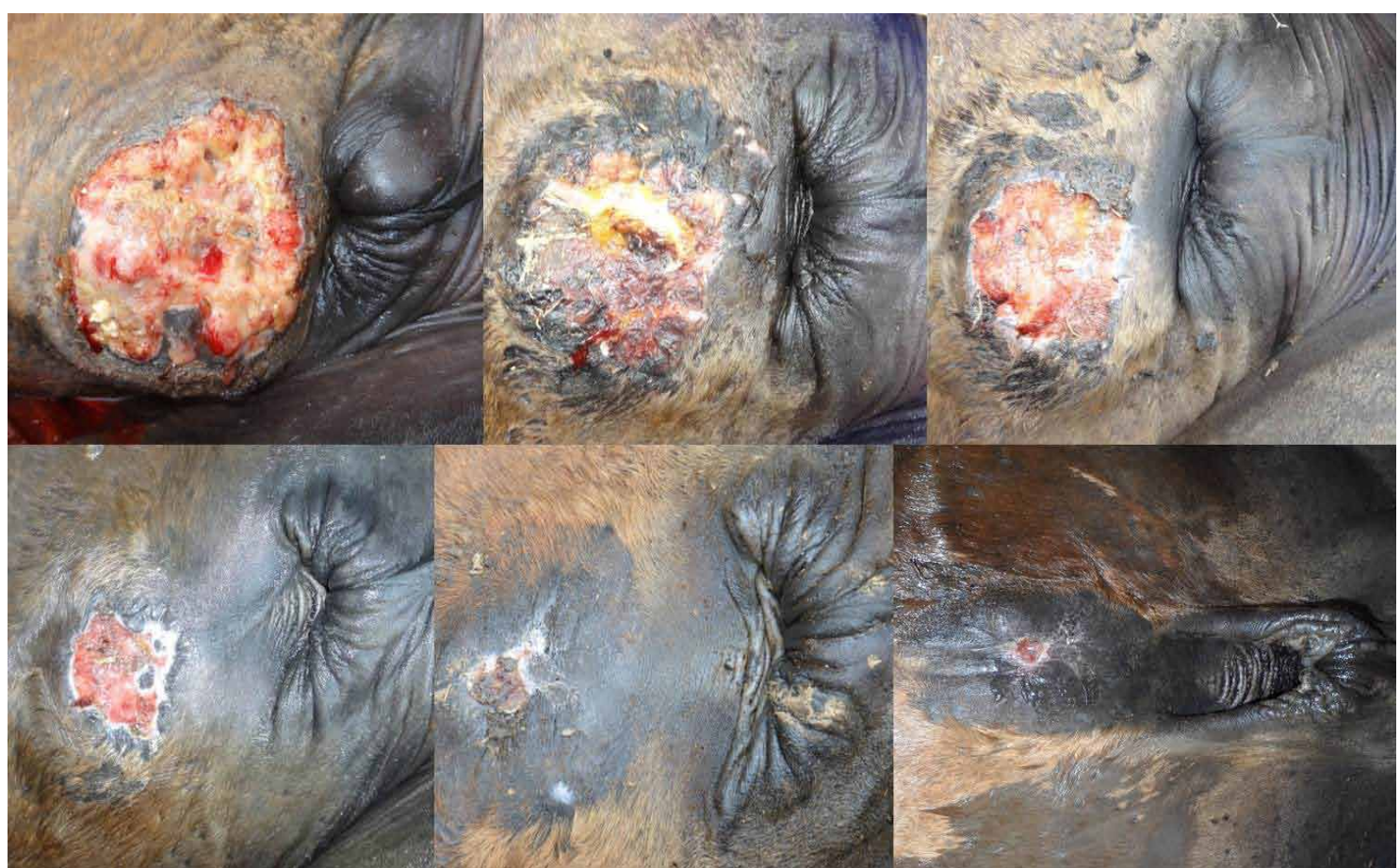

Figure 6. Contraction of the granuloma area in the TG at the abdomen. Note the evolution of wound contraction in a 10-day interval until completely closed at $60 \pm 3.4$ days after application of treatment.

tissues compromising bone structures, which were characterized by tissue fibrosis, moderate exostosis, as well as by osteolysis and osteomyelitis in some areas, in agreement with Zaro (20), who reported irregularities in the bone surface with severe erosions and periosteal reactions in chronic pythiosis cases in horses.

After treatment with triamcinolone acetonide, moderate radioactivity and presence of enthesophytes was observed at day 16 in the cortex of the bone. At day 32 the decrease in radio-opacity areas was more marked, and at day 64 radio-opacity was absent in the tissue, although small focal areas of radioopacity were evident in the cortex of the bone, indicating a decrease in tissue fibrosis and the presence of exostoses as sequelae of the chronicity (Figure 7).

\section{DISCUSSION}

The use of triamcinolone acetonide in horses has not been reported in the treatment of dermatological diseases in horses and even less in the specific case of equine cutaneous pythiosis. For this reason this study constitutes the first report in the treatment of pythiosis with triamcinolone acetonide. en el área de $1.9 \%$ y porcentaje de contracción de $0,0 \%$. Se utilizó el teste $t$ de Student con la que se determinó diferencias altamente significativas $(p=0.0001 \leq 0.05)$ entre los dos grupos (GT y GC). Considerando como variable respuesta a la reducción del área afectada en un período de $60 \pm 3.4$ días en el grupo tratado.

Respecto al seguimiento radiológico de las lesiones cutáneas crónicas localizadas en las partes distales en 3 animales del estudio, se encontró en las proyecciones dorso-palmar y latero-medial, desarrollo o invasión a los tejidos subyacentes comprometiendo estructuras óseas, las cuales se caracterizaron por fibrosis tecidual, exostosis moderada, así como osteólisis y osteomielitis en algunas áreas, concordando con Zaro (20), quien reporto irregularidades en la superficie ósea con severas erosiones y reacciones periósticas en casos de pythiosis crónica en equinos.

Después de la aplicación del tratamiento con acetonida de triamcinolona, al día 16 se observó moderada radio-opacidad y presencia de entesofitos en la cortical del hueso. Al día 32 la disminución de las áreas de radio-opacidad fue más marcada, y al día 64 se observó ausencia de la radio-opacidad en el tejido, aunque se evidenciaran pequeñas áreas focalizadas de radio-opacidad en la cortical del hueso, indicando disminución de la fibrosis tecidual y presencia de exostosis como secuelas de cronicidad (Figura 7). 

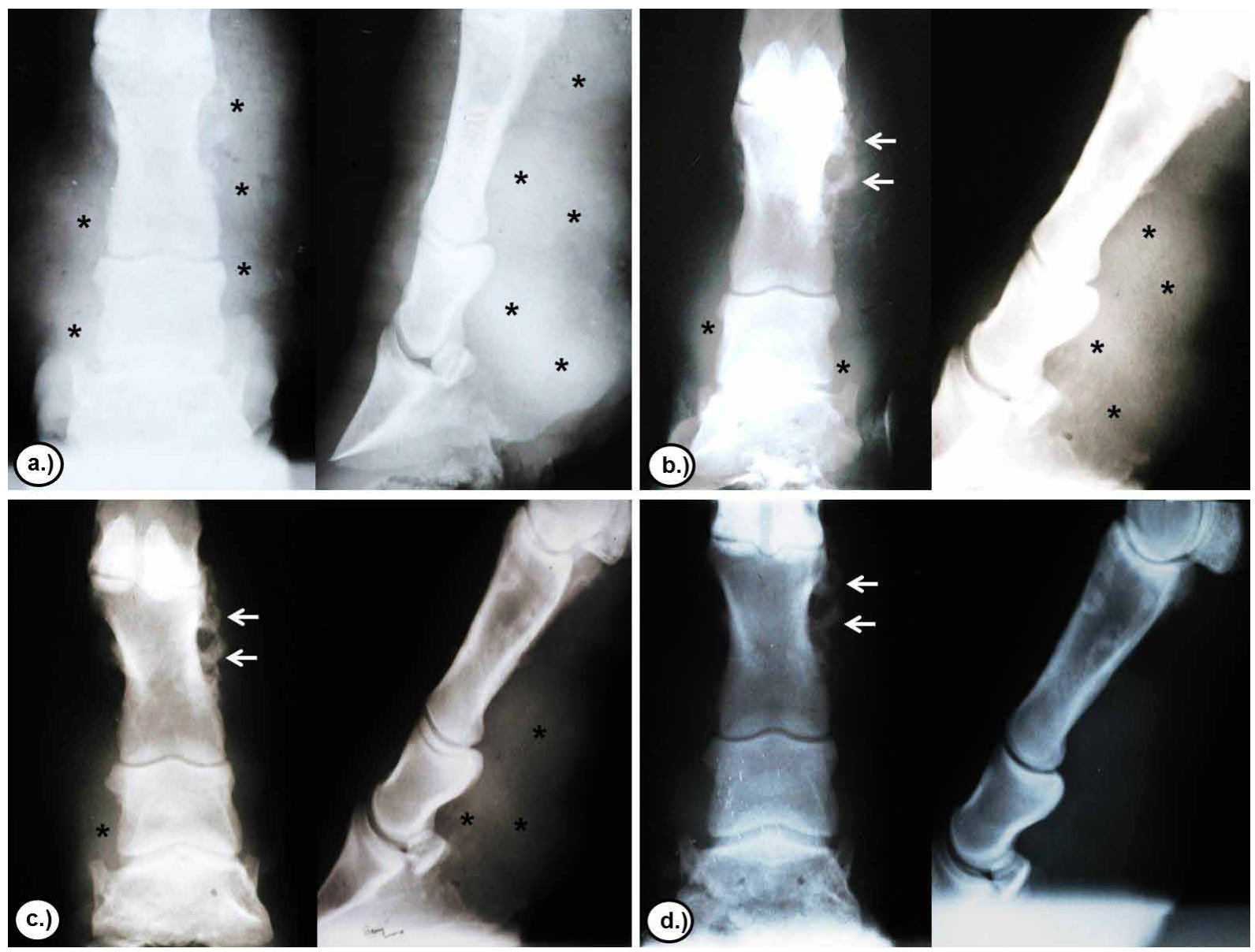

Figure 7. Radiological evaluation of the evolution of chronic skin lesions located in the distal parts of a TG animal after treatment with triamcinolone acetonide. a.) 0 days. b.) 16 days. c.) 32 days. d.) 64 days. Note the reduction in radiopaque areas in the tissue (asterisks) and the preservation of small radiopaque areas in the cortex of the bone (arrows) according to the time of experiment.

Pythiosis is undoubtedly a disease that will not be repaired by first intention, by the infectious process and the granulomatous nature of the lesion, so it will always be more aggressive and proliferative, in which case second intention healing is required due to excessive loss or severe tissue involvement, presence of kunkers, fistulous trajectories and excessive granulation tissue, requiring the administration of a medical treatment to aid in the control of the oomycete infection and to promote tissue repair (3).

Much has been studied on the treatment of equine cutaneous pythiosis, from traditional antifungals, state-of-the-art antimycotics, antibiotic therapy, surgery and immunotherapy; however, none of the treatments studied have given satisfactory results in terms of producing a complete solution for the disease $(5,17,21,22)$.

\section{DISCUSIÓN}

El uso de la acetonida de triamcinolona en caballos no ha sido relatado en el tratamiento de enfermedades dermatológicas en equinos y menos aún en el caso específico de pythiosis cutánea equina, por esa razón el presente estudio constituye el primer reporte en el tratamiento de la pythiosis con acetonida de triamcinolona.

Sin duda la pythiosis es una enfermedad que no va a reparar por primera intención, por el proceso infeccioso y el carácter granulomatoso de la lesión, de modo que siempre es más agresiva y proliferativa, siendo en ese caso necesaria la cicatrización por segunda intención debida a la perdida excesiva o grave comprometimiento tecidual, presencia de kunkers, trayectos fistulosos y excesivo tejido de granulación, siendo necesaria la instauración de un tratamiento médico que ayude en el control de la infección del oomiceto y promueva la reparación tecidual (3). 
The results obtained in this study were satisfactory with $100 \%$ clinical recovery at $60 \pm 3.4$ days after treatment with triamcinolone acetonide in TG, mainly in areas of anatomical compromise where surgery was impossible. The decrease in clinical manifestations is due to the elimination of the injurious agent, which decreases the antigenic stimulus and, hence the large amount of eosinophils, which is used by the Oomycete as a defense mechanism and are the cause of the granulomatous process, pruritus and exudation; kunkers also disappear allowing for the progressive recovery of the injured tissue.

Frey et al (23) reported a 50\% recovery using the Pitium-Vac vaccine associated with the curettage of the necrotic material of the lesions or surgery. Similarly, Pereira et al (21) tested in vitro carposfungin with an action of $63 \%$; however, when tested in vivo, it showed a reduction in lesions, but when the treatment ceased the growth of the lesions restarted. On the other hand, Cavalheiro et al (22) and Argenta (24) studied state-of-theart in vitro antifungals in combination with voriconazole with terbinafine and itraconazole with terbinafine, showing synergism against $17 \%$ of the samples from that study. Biava et al (25) reported unsatisfactory results and a recovery of less than $25 \%$ in studies where amphotericin B, $10 \%$ sodium and potassium iodide, flurocytosine, ketoconazole, and nonsurgery were tested, as well as systemic amphotericin B combined with gauze pads embedded in solutions of amphotericin B and dimethyl sulfoxide (DMSO).

The results obtained with antifungal drugs are controversial, showing unsatisfactory results due to the inability of $P$. insidiosum to produce steroids in the plasma membrane, such as ergosterol, which is the albo-active component of most antifungal drugs (7). State-of-the-art antimycotics such as carposfungin (an inhibitor of $\beta$-glucan synthesis) showed a reduction in lesions, but when the treatment was stopped the growth of the lesions restarted (21); combinations of itraconazole and terbinafine or voriconazole and terbinafine showed some degree of success in comparison with isolates of $P$. insidiosum $(22,24)$. Likewise, Loreto et al (26) reported the in vitro susceptibility of $P$. insidiosum to macrolide antibiotics and tetracyclines by reducing the incorporation of amino acids into proteins.

Gaastra et al (27) recommend surgery as a treatment for the removal of the entire affected area and a safety margin to avoid relapses.
Se ha estudiado mucho sobre el tratamiento de la pythiosis cutánea equina, desde antimicóticos tradicionales, antimicóticos de última generación, antibioticoterapia, cirugía e inmunoterapia, sin embargo, ninguno de los tratamientos estudiados ha dado resultados satisfactorios en el sentido de obtener una solución completa para la enfermedad $(5,17,21,22)$.

Los resultados obtenidos en el presente estudio fueron satisfactorios con $100 \%$ de recuperación clínica a los $60 \pm 3,4$ días después tratamiento con acetonida de triamcinolona en el GT, principalmente en las áreas de compromiso anatómico donde la cirugía era imposible realizar. La disminución de las manifestaciones clínicas se debe a la eliminación del agente injuriante, lo que disminuye el estímulo antigénico $y$, por eso la gran cantidad de eosinófilos, que es utilizado por el Oomiceto como mecanismo de defensa y son los causantes del proceso granulomatoso, del prurito, de la exudación, asimismo desaparecen los kunkers, permitiendo la recuperación progresiva del tejido lesionado.

En cuanto Frey et al (23), reportaron $50 \%$ de recuperación usando la vacuna Pitium-Vac asociada a curetaje del material necrótico de las lesiones o cirugía. Asimismo Pereira et al (21), testaron la carposfungina in vitro con una acción del $63 \%$, sin embargo al ser testada in vivo mostró reducción de las lesiones, pero cuando el tratamiento fue suspendido el crecimiento de las lesiones reinició. Por otro lado, Cavalheiro et al (22) y Argenta (24), estudiaron in vitro antimicóticos de última generación en combinación de voriconazol con terbinafina e itraconazol con terbinafina demostrando sinergismo contra $17 \%$ de las muestras de ese estudio. Biava et al (25) informaron resultados pocos satisfactorios e inferiores al $25 \%$ de recuperación en estudios donde fueron testadas la anfotericina $\mathrm{B}$, yoduro de sodio y de potasio al $10 \%$, flurocitosina, ketoconazol asociados o no a la cirugía, así como la anfotericina B sistémica combinada con compresas de gasas embebidas en soluciones de anfotericina B y dimetilsulfóxido (DMSO).

Los resultados obtenidos con las drogas antimicóticas son controvertidos, con resultados insatisfactorios, debido a la incapacidad del $P$. insidiosum para producir esteroides en la membrana plasmática, como el ergosterol, que es el componente albo de acción de la mayoría de las drogas antimicóticas (7). Los antimicóticos de última generación como la carposfungina (un inhibidor de la síntesis de $\beta$-glucano) mostraron reducción de las lesiones, pero cuando el tratamiento fue suspendido el crecimiento de las lesiones reinició (21); Combinaciones de itraconazol y terbinafina o voriconazol y terbinafina, presentaron algún grado de desempeño contra aislados de $P$. insidiosum $(22,24)$. Asimismo, 
However, in many cases it is difficult because of the degree of involvement of the anatomical structures affected, mainly in the limbs, so they also suggest to use the combination with immunotherapy, potassium iodide, state-ofthe-art antimycotics and antimicrobials as the most suitable treatment for the cure of clinical pythiosis in horses.

The action mechanism of triamcinolone acetonide in the case of equine cutaneous pythiosis is still uncertain, although corticosteroids have a variety of metabolic, endocrine and immunological functions. Clares (28) and Morato (29) stated that the mechanism of the anti-inflammatory and antiallergic activity of glucocorticoid-type corticosteroids is the induction of phospholipase A2 inhibitory proteins, collectively known as lipocortins. These proteins are postulated to control potent mediators of inflammation, such as prostaglandins, thromboxanes, prostacyclins, leukotrienes, and hydroxycyatriatrienoic acids, all synthesized from arachidonic acid, which discharge is catalyzed by the enzyme phospholipase $A_{2}$. As a result of this action, they will have anti-inflammatory effects, such as delayed migration of nuclear polymorphous leukocytes, decreased fibrinogenesis, decreased C-reactive protein production, suppression of mast cell degranulation and immunosuppressive effects, including the suppression of phagocytosis processes and the reduction in the number of eosinophils and lymphocytes.

A possible pharmacological explanation for the recovery of horses with pythiosis treated with triamcinolone acetonide is the mechanism of the glucocorticoid immuno-modulating activity, since it inhibits the synthesis, release and/or action of cytokines and other mediators that promote the inflammatory or immune response. These molecules include proinflammatory cytokines, such as IL-1, IL- 6 and alpha tumor necrosis factor (TNF-a), clonal expansion and IL-2, subset of auxiliary T lymphocytes (Th1), IL-12 and gamma interferon (IFN-Y) and, to a lesser extent, the Th2, IL-4 and IL- 5 subset, colony-stimulating factors such as granulocyte and macrophage (GM-CSF), chemokines such as RANTES and MIP-1a, adhesion molecules such as ICAM1, ELAM-1 and E-selectin, inflammatory mediators such as bradykinin, histamine, eicosanoids and nitric oxide, as well as molecules involved in the presentation of antigen and class II major histocompatibility complex (MHC). The entire spectrum of molecular albs explains pleiotropy and the anti-inflammatory and immunomodulatory
Loréto et al (26), reportaron susceptibilidad in vitro de $P$. insidiosum a los antibióticos macrólidos y tetraciclinas por la reducción de la incorporación de aminoacidos a las proteínas.

Gaastra et al (27), recomiendan como tratamiento la cirugía con retirada de toda el área afectada, y margen de seguridad para evitar las recidivas, sin embargo, en muchos casos se hace difícil por el grado de compromiso de las estructuras anatómicas afectadas, principalmente en los miembros, por lo que además sugieren utilizar la combinación con inmunoterapia, aplicación de yoduro de potasio, antimicóticos de última generación y antimicrobianos como tratamiento más indicado para la cura de la pythiosis clínica en equinos.

El mecanismo de acción de la acetonida de triamcinolona en el caso de la pythiosis cutánea equina aún es incierto, aunque los corticosteroides tienen una variedad de funciones metabólicas, endócrinas e inmunológicas. Clares (28) y Morato (29) exponen que el mecanismo de la actividad antiinflamatoria y antialérgica de los corticosteroides tipo glucocorticoide es la inducción de las proteínas inhibidoras de la fosfolipase $A_{2}$, colectivamente denominadas lipocortinas. Postulase que esas proteínas controlan potentes mediadores de la inflamación, como las prostaglandinas, tromboxanos, prostaciclinas, leucotrienos y ácidos hidroxieicosatrienoicos, todos sintetizados a partir del ácido araquidónico, cuya liberación es catalizada por la enzima fosfolipasa $A_{2}$. Como resultado de esta acción, tendrán efectos antiinflamatorios, como atraso en la migración de leucocitos polimorfo nucleares, disminución de la fibrinogenesis, disminución de la producción de proteína C-reactiva, supresión de la degranulación de mastocitos, y efectos inmunosupresores, incluyendo la supresión de los procesos de fagocitosis y reducción del número de eosinófilos y linfocitos.

Una posible explicación farmacológica en la recuperación de los equinos con pythiosis tratados con acetonida de triamcinolona se encuentra en el mecanismo de la actividad imuno-moduladora de los glucocorticoides, ya que inhibe la síntesis, liberación y/o acción de citocinas y otros mediadores que promueven la respuesta inflamatoria o inmune. Estas moléculas incluyen citocinas proinflamatorias, tales como IL-1, IL-6 y factor de necrosis tumoral alfa (TNF-a), la expansión clonal y IL-2, subconjunto de linfocitos $T$ auxiliares (Th1), IL-12 e interferón gama (IFN-Y) y, en menor extensión, el subconjunto Th2, IL-4 y IL-5, factores estimulantes de colonias, tales como los factores estimulantes de colonias de granulocitos y macrófagos (GM-CSF), las quimiocinas como RANTES y MIP-1 a, moléculas de adhesión tales como ICAM1, ELAM-1 y E-selectina, los mediadores inflamatorios tales como bradicinina, histamina, 
force. This is why blocking the synthesis of IL-5 cytokine and granulocyte-macrophage colonystimulating factors (GM-CSF) triggers the programmed death of these cells (apoptosis), which decreases the half-life of eosinophil, since cytokine (IL-5) is responsible for eosinophilopoiesis, increasing the function of mature eosinophils as well as degranulation, adhesion and cytotoxicity, thus prolonging the survival of that cell (30).

According to the results obtained in this study, it can be concluded that triamcinolone acetonide was effective in the treatment of granulomatous wounds by pythiosis, showing clinical recovery in all animals treated. Therefore, the use of triamcinolone acetonide can be recommended as a suitable therapeutic alternative in the treatment of equine cutaneous pythiosis. Although there are many factors that affect the action of drugs in diseased animals, such as $\mathrm{pH}$, vascularization, fibrosis, idiosyncrasy, species variations, tolerance, sensitivity, nutritional status and body condition of the animal, it is necessary to perform further field trials in naturally infected animals considering triamcinolone acetonide alone or in combination with other therapeutic options. eicosanoides y óxido nítrico, bien como moléculas comprometidas en la presentación de antígeno y complejo principal de histocompatibilidad (MHC) de clase II. Todo el espectro de albos moleculares explica tanto la pleiotropía como la fuerza antiinflamatoria e inmunomoduladora. Es por eso que al bloquear la síntesis de la citocina IL-5 y el factor estimulante de colonias de granulocitos y macrófagos (GM-CSF), se desencadena la muerte programada de estas células (apoptosis), lo que disminuye la vida media de los eosinófilo, una vez que esta citocina (IL-5) se encarga de la eosinófilopoyesis, causando el aumento de la función de los eosinófilos maduros, así como la degranulación, adherencia y citotoxicidad, prolongando así la sobrevivencia de esa célula (30).

De acuerdo con los resultados obtenidos en el presente estudio, se puede concluir que la acetonida de triamcinolona fue efectiva en el tratamiento de heridas granulomatosas por pythiosis, mostrando recuperación clínica en todos los animales tratados. Por lo tanto se puede recomendar el uso de la acetonida de triamcinolona como una buena alternativa terapéutica en el tratamiento de la pythiosis cutánea equina. Aunque son muchos los factores que afectan la acción de los fármacos en el animal enfermo, como es el pH, vascularización, fibrosis, idiosincrasia, variaciones de la especie, tolerancia, sensibilidad, estado nutricional y condición corporal del animal, es necesario la realización de mayores pesquisas de campo en animales naturalmente infectados considerando la acetonida de triamcinolona aisladamente o en combinación con otras opciones terapéuticas.

\section{REFERENCES}

1. Fonseca $A$, Botton $S$, Nogueira $C$, Correa $B$, Silveira J, Azevedo M, Maroneze B, Santurio J, Pereira D. In Vitro Reproduction of the Life Cycle of Pythium insidiosum from Kunkers' Equine and Their Role in the Epidemiology of Pythiosis. Mycopathologia 2014; 177:123-127.

2. Cardona J, Vargas M, González M. Evaluación clínica e histopatológica de la pythiosis cutánea en terneros del departamento de Córdoba, Colombia. Rev MVZ Córdoba 2013; 18(2):3551-3558.

3. Cardona J, Vargas M, Perdomo S. Pythiosis cutánea equina: una revisión. Rev Ces Med Vet Zootec 2013b; 8(1):58-67.

4. Cardona J, Vargas M, Perdomo S. Frecuencia de Pythiosis cutánea en caballos de producción en explotaciones ganaderas de Córdoba, Colombia. Rev Med Vet Zoot 2014; 61(1):31-43.
5. Santos C, Santurio J, Marques C. Pitiose em animais de produção no Pantanal Matogrossense. Pesq Vet Bras 2011a; 31(12):1083-1089.

6. White S. Equine Bacterial and Fungal Diseases: A Diagnostic and Therapeutic Update. Clin Tech Equine Pract 2005; 4:302-310.

7. Luis-León J, Pérez R. Pythiosis: Una patología emergente en Venezuela. Salus online 2011; 15(1):79-94.

8. Santurio J, Alves S, Pereira D, Argenta J. Pitiose: uma micose emergente. Act Sci Vet 2006; 34(1):1-14.

9. Marcolongo-Pereira C, Estima-Silva P, Soares M, Sallis S, Grecco F, Raffi M, Fernandes C, Schild A. Doenças de equinos na região Sul do Rio Grande do Sul. Pesq Vet Bras 2014; 34(3):205-210. 
10. Cardona J, Vargas M, Perdomo S. Pythiosis cutánea equina en el departamento de Sucre, Colombia. REDVET 2012; 13(11):1-7.

11. Cardona J, Vargas M, Perdomo S. Evaluación clínica e histopatológica de la pitiosis cutánea en burros (Equus asinus). Rev Med Vet 2013c; 25:9-19.

12. Mrad A. Ética en la investigación con modelos animales experimentales. Alternativas y las 3 RS de Russel. Una responsabilidad y un compromiso ético que nos compete a todos. Rev Col Bioética 2006; 1(1):163-184.

13. Pabón J, Eslava J, Gómez R. Generalidades de la distribución espacial y temporal de la temperatura del aire y de la precipitación en Colombia. Meteorol Colomb 2001; 4:47-59.

14. Ayres M, Murcia C, Ayres D, Santos S. BioEstat 5.0: Aplicações estatísticas em ciências biológicas e medicina. Belém, Sociedade Civil Mamirauá, Brasilia DF; 2004.

15. Statistical Analysis System. SAS OnlineDoc 9.1.3. Institute Inc, Cary, NC, USA. 2007.

16. Márquez A, Salas $Y$, Canelón J, Perazzo $Y$, Colmenárez V. Descripción anatomopatológica de pitiosis cutánea en equinos. Rev Fac Cs Vets UCV 2010; 51(1):37-42.

17. Santos C, Santurio J, Colodel E, Juliano R, Silva J, Marques L. Contribuição ao estudo da pitiose cutânea equina em equídeos do pantanal norte, Brasil. Ars Vet 2011b; 27(3):134-40.

18. Dória R, Freitas $S$, Mendonça F, Arruda L, Boabaid F, Filho A, Colodel E, Valadão E. Utilização da técnica de imuno-histoquímica para confirmar casos de pitiose cutânea equina diagnosticados por meio de caracterização clínica e avaliação histopatológica. Arq Bras Med Vet Zootec 2014; 66(1):27-33.

19. Galiza G, da Silva T, Caprioli R, Barros C, Irigoyen L, Fighera R, Lovato M, Kommers G. Ocorrência de micoses e pitiose em animais domésticos: 230 casos. Pesq Vet Bras 2014; 34(3):224-232.

20. Zaro D. 2013. Pythium Insidiosum: Revisão Literária y relato de caso em equino. Brasil. Universidade Federal Do Rio Grande Do Sul. [acceso febrero 12 de 2016] URL Disponible en: http://www.lume.ufrgs.br/ bitstream/handle/10183/95099/000917573. pdf?sequence $=1$
21. Pereira D, Santurio J, Alves S, Argenta J, Potter L, Spanamberg A, Ferreiro L. Caspofungin in vitro and in vivo activity against Brazilian Pythium insidiosum strains isolated from animals. ] Antimicrob Chemother 2007; 60:1168-1171.

22. Cavalheiro A, Maboni G, Azevedo M, Argenta J, Pereira D, Spader T, Alves S, Santurio J. In Vitro Activity of Terbinafine Combined with Caspofungin and Azoles against Pythium insidiosum. Antimicrob Agents Chemother 2009; 53(5):2136-2138.

23. Frey F, Velho J, Lins L, Nogueira C, Santurio J. Pitiose equina na região sul do Brasil. Rev Port Cienc Vet 2007; 102:107-111.

24. Argenta J. Atividade in vitro, individual ou em combinação, de voriconazol, itraconazol e terbinafina contra isolados brasileiros de Pythium insidiosum. Acta Scientiae Veterinariae 2008; 36(3):327-328.

25. Biava J, Ollhoff D, Gonçalves R, Biondo A. Zigomicose em equinos-revisão. Rev Acad Curitiba 2007; 5:225-230.

26. Loreto E, Nunes-Mario D, Denardi L, Alves S, Santurio J. In Vitro Susceptibility of Pythium insidiosum to Macrolides and Tetracycline Antibiotics. Antimicrob. Agents Chemother. 2011; 55(7):3588-3590.

27. Gaastra W, Lipman L, De Cock A, Exel T, Pegge R, Scheurwater J, Vilela R, Mendoza L. Pythium insidiosum: An overview. Vet Microbiol 2010; 146:1-16.

28. Clares B. Sistemas de transporte y liberación de farmacos de aplicación tópica: liposomas multilaminares portadores de Acetonido de Triancinolona. [Tesis Doctoral]. España: Universidad de Granada; 2003. [Fecha de acceso 12 de febrero de 2016] URL Disponible en: http://digibug.ugr.es/ bitstream/10481/2113/1/17722238.pdf

29. Morato L. Utilização da triancinolona como agente modulador da resposta inflamatória na cirurgia de músculo extra-ocular em coelhos. [Tese Ph.D.] Brasil. Universidade de São Paulo, Faculdade de Medicina; 2006. [acceso febrero de 2016] URL Disponible en: http://www.teses.usp. br/teses/disponiveis/5/5149/tde-25042007093133/publico/Luisemrcarvalhotese.pdf

30. Liberman A, Druker J, Perone M, Arzt E. Glucocorticoids in the regulation of transcription factors that control cytokine synthesis. Cytokine Growth Factor Rev 2007; 18:45-56. 